Full-text Available Online at www. bioline.org.br/ja
J. Appl. Sci. Environ. Mgt. June, 2006

Vol. $10(2) 23-27$

\title{
Trace Metal Levels in Raw and Heat Processed Nigerian Staple Foods from Oil- Producing Areas of Rivers and Bayelsa States
}

\author{
AKANINWOR, J O; ONYEIKE, E N; IFEMEJE, J C \\ Department of biochemistry, university of port Harcourt, P. M. B 5323, \\ Port Harcourt, Rivers State, Nigeria
}

\begin{abstract}
The levels of some trace metals (Fe, $\mathrm{Zn}, \mathrm{Cu}, \mathrm{Ni}, \mathrm{Cd}$ ) were quantitatively determined in raw and heat processed staple food cultivars (yam, cassava, cocoyam and maize) from oil producing areas of part of the Niger Delta and compared with a non-oil producing area of Ebonyi State as control. The survey was conducted to evaluate the role of foods as exogenous source of these metals among the inhabitants. The data showed that metal levels in all the raw staple foods from oil producing areas were significantly higher at $(\mathrm{p}<0.05)$ than those from non-oil producing areas. However, lead levels of all the raw staple foods in all the studied areas were below detectable levels. Exceedingly higher levels of these metals characterized the raw staple food cultivars from oil producing areas than those from non-oil producing area and on heat treatment the levels were reduced. These high levels are indicative of extensive pollution in these areas understudied suggesting possible health risks in consumption of food cultivars from such areas. @JASEM
\end{abstract}

Eleme, Ogoni, Okrika and Nembe in Rivers and Bayelsa States of the Niger Delta region of Nigeria are fraught with petroleum exploration and exploitation, refining and other oil-related industrial activities that have led to a wide pollution of its rivers, swamps and farmlands with hydrocarbons and dispersant products . These regions in the Niger Delta area of Nigeria have been subjected to severe and constant crude oil spillage as a result of the intensive activities of oil prospecting companies. The extensive pollution of environments in the Niger Delta constitute socio-economic and public health hazards (Kobashi and Rithman, 1982; Smith and Dragun 1984). Crude oil contamination leads to decreased Cation exchange in soils according to the type and degree of contamination (Wagner and Miehlich, 1992). Crude oil exerts adverse effects on plants indirectly by making toxic minerals in the soil more available to plants. (Adam and Ellis, 1960).

Essential elements such as iron, zinc, copper, nickel and magnesium are associated with enzyme systems particularly those involved in oxidation process and other important biochemical processes (Crosby, 1977). The metabolic functions of essential elements have been classified as electrochemical, catalytic, structural and miscellaneous groups. (Bomen, 1966). Examples of the first group are sodium (Na), Potassium, calcium and magnesium which exist inside cells in the ionic state at concentrations that differ from those in the surrounding medium. Catalytic functions arise through an association with enzyme systems. Some metals exist as chelate complexes, for instance, magnesium $(\mathrm{Mg})$ in the chlorophll, iron (Fe) in the porphyrins and Cobalt in vitamin $\mathrm{B}_{12}$. Other elements such as arsenic (As), lead $(\mathrm{Pb})$, cadmium $(\mathrm{Cd})$ and mercury $(\mathrm{Hg})$ are known to be non-essential and toxic at very low levels of intakes. However, the presence of essential nutrient metals in excess of the required threshold concentrations in the body can trigger some toxic sequalae. Both heavy metals like mercury (Hg), Arsenic (As), lead (Pb) and cadmium (Cd) as well as essential nutrient metals like iron (Fe), zinc ( $\mathrm{Zn})$, copper $(\mathrm{Cu})$, are present in the soil, in natural water and atmosphere (air) in various forms and these may become contaminants of food and feeding stuffs. Pathological precedence in industrialized or mining regions has implicated metals as serious culprits in organ-system diseases. Incidents of metallic poisoning arising from contamination of foods and feeding stuffs are well documented in literature (Watanabe et al, 1985, 1989, Tabaku and Panariti, 1996). The auditing and monitoring of metals in the environment (soil, water and foods) are fast becoming an essential aspect of pollution studies, particularly in industrialized area. This study is one such attempts to evaluate the status of $\mathrm{Fe}, \mathrm{Zn}, \mathrm{Cu}, \mathrm{Ni}, \mathrm{Cd}$ and $\mathrm{Pb}$ in staple food cultivars from oil-producing areas of Eleme, Ogoni, Okrika, Nembe and non-oil producing area (Abakaliki) as control.

\section{MATERIALS AND METHODS}

Sample collection and treatment: The food crops were harvested fresh from farmlands from the studied areas. These food samples collected include tubers (yam, cassava), corm (cocoyam), cereal (maize). Garri and fufu (processed forms of cassava) were obtained from the studied areas for analysis. Yam, cassava, cocoyam were peeled to remove their coats. They were sliced and dried in an electric oven at the temperature of $100^{\circ} \mathrm{C}$ for 12 hours along with other test food samples. Dry samples were then ground into powder in a mortar. 2.0g of each ground sample was weighed into a boiling tube and $10.0 \mathrm{ml}$ of a digesting mixture made up of perchloric acid and concentrated nitric acid, in a 1:2 ratio was added, swirled and kept in the fume cupboard overnight. Samples were 
subsequently digested at the temperature of $150^{\circ} \mathrm{C}$ on a hot plate for $45 \mathrm{~min}$ until frothing ceased the contents were cooled for $10 \mathrm{~min}$. $5.0 \mathrm{ml}$ of $6.0 \mathrm{~m}$ hydrochloric acid was added to the cooled digest and further digested for 30mins. The tubes were then removed from the hot plate, allowed to cool and the contents of each made up to $50 \mathrm{ml}$ with deionised water. The resulting solution was analyzed with an atomic absorption spectrophotometer (AAS). The absorption of radiation by iron, zinc, copper, nickel, cadmium and lead produced from the sample solutions at various wavelengths were measured using the AAS (Buck Scientific Model 200A System). The spectrophotometer was standardized using the standard solution of the element being analyzed and acidified deionized water was aspirated to zero the instrument. Air/acetylene flame was used and sample extracts were aspirated and concentrations read-off the instrument.

\section{RESULTS AND DISCUSSION}

Tables 1-4 show the mean concentrations of trace metals in parts per million (ppm) in the various raw and heat processed staple foods (yam,. Cassava, cocoyam and maize) from oil-producing areas of Rivers, Bayelsa States.

Iron, and zinc levels of raw staple foods from oil producing areas were significantly higher $(\mathrm{p}<0.05)$ than that from Abakaliki. The high levels of iron may be due to soil high organic matter, high $\mathrm{pH}$, natural complexing ligands that enhance zinc transport and uptake in plants (John and Vanlearhoven, 1972, Khan and Frankland 1983, Ezeonu et al, 2002). Iron levels (41.50 $\pm 0.25 \mathrm{ppm}-52.75 \pm 0.00 \mathrm{ppm})$ and zinc levels $(28.58 \pm 0.00-59.78 \pm 0.00 \mathrm{ppm})$ were above maximum recommended daily allowance of $18 \mathrm{mgFe} /$ day and $10-15 \mathrm{mg} \mathrm{Zn} /$ day respectively (Wayne and Dale, 1989), iron and zinc concentrations of heat processed staple foods except garri decreased when compared to those of the raw samples. This may be as a result of loss of iron to the cooking water which was discarded. This report is similar to earlier report that boiling of yam and cocoyam resulted in the removal of free amino acid and a considerable reduction in the amount of minerals (Eka, 1987).

Table 1: Concentrations of trace metals (ppm) of raw and heat processed yam tuber from different locations (Eleme, Ogoni, Okrika, Nembe and Abakaliki) Concentrations of trace metals (ppm)

\begin{tabular}{|c|c|c|c|c|c|c|c|c|c|c|}
\hline & \multicolumn{10}{|c|}{ Constituents } \\
\hline & \multicolumn{5}{|c|}{ Raw Samples in Locations } & \multicolumn{5}{|c|}{ Heat Processed Samples in Locations } \\
\hline & Eleme & Ogoni & Okrika & Nembe & Abakaliki & Eleme & Ogoni & Okrika & Nembe & Abakaliki \\
\hline $\mathrm{Fe}$ & $52.75 \pm 0.00^{\mathrm{a}}$ & $48.75 \pm 0.25^{b}$ & $41.50 \pm 0.25^{\mathrm{d}}$ & $46.76 \pm 0.00^{c}$ & $33.58 \pm 0.14^{\mathrm{c}}$ & $49.50 \pm 0.25^{\mathrm{a}}$ & $41.00 \pm 0.28^{\mathrm{b}}$ & $26.25 \pm 0.25^{\mathrm{d}}$ & $36.67 \pm 0.14^{\mathrm{c}}$ & $26.42 \pm 0.14^{\mathrm{d}}$ \\
\hline $\mathrm{Zn}$ & $38.27 \pm 0.03^{\mathrm{a}}$ & $28.58 \pm 0.00^{\mathrm{b}}$ & $15.73 \pm 0.00^{\mathrm{a}}$ & $15.90 \pm 0.00^{\mathrm{d}}$ & $16.44 \pm 0.01^{\mathrm{c}}$ & $28.30 \pm 0.15^{\mathrm{a}}$ & $24.70 \pm 0.00^{\mathrm{b}}$ & $13.78 \pm 0.03^{\mathrm{c}, \mathrm{d}}$ & $15.60 \pm 2.43^{\mathrm{c}}$ & $13.55 \pm 0.00^{\mathrm{d}}$ \\
\hline $\mathrm{Cu}$ & $5.83 \pm 0.14^{\mathrm{a}}$ & $4.08 \pm 0.14^{\mathrm{b}}$ & $3.33 \pm 0.25^{\mathrm{c}}$ & $3.92 \pm 0.14^{\mathrm{b}}$ & $3.83 \pm 0.14^{\mathrm{b}}$ & $3.17 \pm 0.14^{\mathrm{a}, \mathrm{b}}$ & $3.08 \pm 0.29^{\mathrm{a}, \mathrm{b}, \mathrm{c}}$ & $3.33 \pm 0.15^{\mathrm{a}}$ & $2.83 \pm 0.14^{\mathrm{c}}$ & $3.08 \pm 0.14^{\mathrm{b}, \mathrm{c}}$ \\
\hline $\mathrm{Ni}$ & $4.50 \pm 0.00^{\mathrm{a}}$ & $3.17 \pm 0.28^{\mathrm{b}}$ & $3.08 \pm 0.14^{\mathrm{b}}$ & $4.25 \pm 0.25^{\mathrm{a}}$ & $3.08 \pm 0.14^{\mathrm{b}}$ & $3.50 \pm 0.25^{\mathrm{b}}$ & $3,00 \pm 0.14^{c}$ & $2.92 \pm 0.14^{\mathrm{d}}$ & $3.50 \pm 0.14^{\mathrm{a}}$ & $3.25 \pm 0.14^{\mathrm{b}}$ \\
\hline $\mathrm{Cd}$ & $0.28 \pm 0.03^{\mathrm{a}}$ & BDL & BDL & BDL & BDL & $0.23 \pm 0.03^{\mathrm{a}}$ & $\mathrm{BDL}$ & $\mathrm{BDL}$ & $\mathrm{BDL}$ & BDL \\
\hline $\mathrm{Pb}$ & BDL & BDL & BDL & BDL & BDL & BDL & BDL & BDL & $\mathrm{BDl}$ & BDL \\
\hline
\end{tabular}

*Value are means \pm standard deviation of triplicate determinations. Values in the same row (for raw and heat processed yam) bearing the same superscript letters are not significantly at $5 \%$ level $(P<0.05)$.

Table 2: connections of trace metals (ppm) of raw and heat processed yam tuber from oil producing areas (Eleme, Ogoni, Okrika, Nembe) and Abakaliki concentrations of trace metals (ppm)*

\begin{tabular}{|c|c|c|c|c|c|}
\hline & \multicolumn{5}{|c|}{ Heat Processed Sample in Locations } \\
\hline & Eleme & Ogoni & Okrika & Nembe & Abakaliki \\
\hline $\mathrm{Fe}$ & $49.50+0.25^{\mathrm{a}}$ & $41.00 \pm 0.00^{\mathrm{b}}$ & $26.25 \pm 0.25^{b}$ & $36.67 \pm 0.14^{c}$ & $26.42 \pm 0.14^{d}$ \\
\hline $\mathrm{Zn}$ & $28.30 \pm 0.00^{\mathrm{a}}$ & $24.70 \pm 0.00^{\mathrm{b}}$ & $13.78 \pm 0.03^{\mathrm{cd}}$ & $15.60 \pm 2.43^{\mathrm{c}}$ & $13.55+0.00^{\mathrm{d}}$ \\
\hline $\mathrm{Cu}$ & $3.17 \pm 0.14^{\mathrm{ab}}$ & $3.08 \pm 0.14^{\mathrm{abc}}$ & $3.33 \pm 0.15^{\mathrm{a}}$ & $2.84 \pm 0.14^{\mathrm{c}}$ & $3.08+0.14^{\mathrm{bc}}$ \\
\hline $\mathrm{Ni}$ & $3.50 \pm 0.25^{\mathrm{a}}$ & $3.00 \pm 0.14^{c}$ & $2.92 \pm 0.14^{\mathrm{d}}$ & $3.50 \pm 0.14^{\mathrm{a}}$ & $3.25 \pm 0.14^{\mathrm{b}}$ \\
\hline $\mathrm{Cd}$ & $023 \pm 0.003 a$ & $\overline{\mathrm{BDL}}$ & $\mathrm{BDL}$ & BDL & $\overline{\mathrm{BDL}}$ \\
\hline $\mathrm{Pb}$ & $\overline{\mathrm{BDL}}$ & BDL & $\mathrm{BDL}$ & $\mathrm{BDL}$ & BDL \\
\hline
\end{tabular}

(for raw and heat processed) bearing the same superscript letters are not significantly different at $5 \%$ level $(P<0.05)$

However, the values of iron in heat processed garri and fufu increased probably due to contamination of the food sample during processing. Macrae et al (1993) reported that processing of foods may contribute to increase in concentration of iron naturally present in the food stuff. The dietary intake of these trace metals in human is based on their values in processed form as this is the form in which these food crops are taken. Iron and zinc concentrations of some heat processed staple foods from oil-producing areas exceeded the maximum recommended dietary allowance of 18mg Fe/day and 10-15mg Zn/day respectively (Wayne and Dale, 1989). Above the recommended dietary allowance may result to iron/zinc overload in the population and this may lead to gastroenteritis and abdominal pains which has been reported as consequential cause of human iron and zinc overload (Macrae et al, 1993). There is no observable trend of copper concentration in raw staple food samples across the locations. This may suggest that copper concentrations of these staple foods were not only based on copper status of the soil but also the 
competing ligands which may influence the absorption and uptake of copper by these food crops. This is because biological interaction of elements occur due to similarities in the physicochemical properties of their ions; ions with similar valence shell electronic structure are likely to be antagonistic (Sandstead, 1995, Hill, 1976).

Table 3: connections of trace metals (ppm) of raw and heat processed cassava from oil Producing areas (eleme, ogoni, okrika, Nembe) and abakaliki concentrations of trace metals (ppm)*

\begin{tabular}{|c|c|c|c|c|c|}
\hline & \multicolumn{5}{|c|}{ Raw Sample in Locations } \\
\hline & Eleme & Ogoni & Okrika & Nembe & Abakaliki \\
\hline $\mathrm{Fe}$ & $45.25+0.25^{\mathrm{a}}$ & $36.00 \pm 0.25^{c}$ & $35.42 \pm 0.14^{\mathrm{d}}$ & $42.00 \pm 0.00^{c}$ & $23.27 \pm 0.03^{\mathrm{e}}$ \\
\hline $\mathrm{Zn}$ & $33.85+0.13^{\mathrm{a}}$ & $14.25+0.00^{\mathrm{d}}$ & $14.55+0.03^{c}$ & $22.38+0.03^{b}$ & $13.68+0.05^{\mathrm{e}}$ \\
\hline $\mathrm{Cu}$ & $1.25 \pm 0.00^{\mathrm{b}}$ & $2.08+0.14^{\mathrm{a}}$ & $1.25 \pm 0.00^{\mathrm{b}}$ & $1.23+0.14^{\mathrm{b}}$ & $1.25 \pm 0.00^{\mathrm{b}}$ \\
\hline $\mathrm{Ni}$ & $6.50 \pm 0.25^{\mathrm{a}}$ & $4.58+0.14^{c}$ & $4.58+0.14^{c}$ & $5.17 \pm 0.14^{\mathrm{a}}$ & $4.58+0.14^{c}$ \\
\hline $\mathrm{Cd}$ & $\overline{\mathrm{BD}} \mathrm{L}$ & $\overline{B D L}$ & $\overline{\mathrm{BDL}}$ & $0.20 \pm 0.00^{\mathrm{a}}$ & $\overline{\mathrm{BDL}}$ \\
\hline $\mathrm{Pb}$ & BDL & BDL & BDL & BDL & BDL \\
\hline
\end{tabular}

Copper levels of heat processed foods in all the locations decreased as a result of loss of mineral to cooking water when discarded (Eka, 1987). The levels $(1.03 \pm 0.14-2.83 \pm 0.14 \mathrm{ppm})$ are within safe recommended dietary allowance of $1.5-3.0 \mathrm{mg} \mathrm{Cu} /$ day (Guthrie and Picciano, 1995), except copper concentrations of heat processed yam and cocoyam from Ogoni, Nembe and Eleme $(3.17 \pm 0.14$ $4.42 \pm 0.14 \mathrm{ppm})$. The elevated copper levels in heat processed foods from oil producing areas above safe recommended dietary allowance of $1.50 \mathrm{mg}$ $3.00 \mathrm{mgCu} /$ day without a corresponding intake of dietary zinc may result in accumulation of copper in the liver which may lead to Wilson's disease and may also result to liver necrosis (Sandstead, 1995). Nickel concentrations of raw staple foods from oil producing areas $(3.02 \pm 0.14-6.50 \pm 0.25 \mathrm{ppm})$ were generally higher than those from Abakaliki $(2.92 \pm 0.14 \mathrm{ppm}-$ $4.58 \pm 0.14 \mathrm{ppm})$. The elevated levels of nickel in raw staple foods from oil producing areas could be as a result of oil and gas pollution of the farm land which resulted in high nickel burden of the soil, increased organic matter content of effluent discharge into the farmlands (John et al, 1972). There was a decrease in nickel concentration of some heat processed food samples. Contrary to expectation, nickel levels of garri and fufu increased compared to the raw sample. Generally, the levels of nickel in both raw and heat processed food samples were low compared to the recommended dietary allowance of $150 \mu \mathrm{g} / \mathrm{day}$ (WHO-IPCS, 1991). Increased level of nickel in some heat processed food samples when compared to the raw sample, may be attributable to nickel contamination of the food sample during processing as nickel is being used in electroplating of machines and cooking utensils. Thus processing of garri and fufu may result in increased nickel content when such machines are used (Macrae et al 1993).

Table 4: connections of trace metals (ppm) of raw and heat processed cassava from oil Producing areas (Eleme, Ogoni, Okrika, Nembe) and Abakaliki Concentrations of trace metals (ppm)*

\begin{tabular}{cccccc}
\hline \multicolumn{5}{c}{ and Abakaliki Concentrations of trace metals (ppm)* } \\
\hline \multicolumn{5}{c}{ Heat Processed Samples (Garri) in Locations } \\
$\mathrm{Fe}$ & $47.25 \pm 0.00^{\mathrm{b}}$ & $42.04 \pm 0.08^{\mathrm{c}}$ & $39.25 \pm 0.25^{\mathrm{d}}$ & $50.33 \pm 0.58^{\mathrm{a}}$ & Abakaliki \\
$\mathrm{Zn}$ & $11.86 \pm 0.01^{\mathrm{d}}$ & $13.55 \pm 0.00^{\mathrm{b}}$ & $12.35 \pm 0.00^{\mathrm{c}}$ & $19.80 \pm 0.00^{\mathrm{a}}$ & $10.78 \pm 0.04^{\mathrm{e}}$ \\
$\mathrm{Cu}$ & $1.25 \pm 0.00^{\mathrm{b}}$ & $1.25 \pm 0.00^{\mathrm{b}}$ & $1.33 \pm 0.14^{\mathrm{b}}$ & $1.3 \pm 0.00^{\mathrm{b}}$ & $1.33 \pm 0.14^{\mathrm{b}}$ \\
$\mathrm{Ni}$ & $3.83 \pm 0.14^{\mathrm{b}}$ & $6.08 \pm 0.14^{\mathrm{a}}$ & $3.83 \pm 0.14^{\mathrm{b}}$ & $6.08 \pm 0.14^{\mathrm{a}}$ & $2.17 \pm 0.14^{\mathrm{c}}$ \\
$\mathrm{Cd}$ & $\mathrm{BDL}$ & $\mathrm{BDL}$ & $\mathrm{BDL}$ & $0.21 \pm 0.01^{\mathrm{a}}$ & $\mathrm{BDL}$ \\
$\mathrm{Pb}$ & $\mathrm{BDL}$ & $\mathrm{BDL}$ & $\mathrm{BDL}$ & $\mathrm{BDL}$ & $\mathrm{BDL}$ \\
\hline \multicolumn{5}{c}{ Values are means + standard deviation of triplicate determinations. Values in the same row (for raw and heat } \\
processed) bearing the same superscript letters are not significantly different at 5\% level (P<0.05).
\end{tabular}

The level of cadmium in some raw staple foods from oil producing areas $(0.12 \pm 0.03-0.28 \pm 0.03 \mathrm{ppm})$ were higher than cadmium levels in raw staple foods from Abakaliki which were below detectable levels. These high levels may be as a result of high cadmium status of the farmland. High cadmium levels of the soil could be due to crude oil pollution, deposition of cadmium particles/fumes released during effluent gas flaring, hydrocarbon pollution and water run-off (Kakulu et al, 1985). Industrial and traffic activities also contribute to cadmium burden of the food crops in these areas (John et al 1972). Immobilization of cadmium in the soil which is dependent on the clay concentration of the soil and its uptake by plant can ultimately lead to increased toxicity of the contaminated soil (Khan and Frankland, 1983). The 
levels of cadmium in heat processed foods from different oil-producing areas except Eleme and Nembe were below detectable levels. Thus, the cadmium levels of heat processed foods were lower than that of raw foods. The levels of dietary intake of cadmium in these food samples from oil-producing areas were higher compared to those of Abakaliki but below World Health Organization Safe Standard of $1.5 \mu \mathrm{g} /$ day. This may suggest that the population feeding on these staple foods from oil producing areas are at higher risk of cadmium toxicity than those feeding from staple foods from Abakaliki. The accumulation of cadmium in the system may lead to acute cadmium poisoning which includes high blood pressure, kidney damage, destruction of testicular tissue and destruction of red blood cells (Goyer, and Cherian, 1992). In pregnant women, normal dietary level exposure of cadmium may cause teratogenic and mutagenic effects on the foetus (Macrae et al, 1993). The levels of lead $(\mathrm{Pb})$ in all the food samples (both raw and heat processed) from different locations of oil-producing areas and Abakaliki were below detectable levels. The very low levels of $\mathrm{Pb}$ in food crops could be as a result of high level of iron $(\mathrm{Fe})$, zinc ( $\mathrm{Zn})$ and calcium (Ca) in the farmland thus reducing lead $(\mathrm{Pb})$ absorption in the plant tissue due to similarities in size. This is supported by the report that higher affinity for essential trace metals $\mathrm{Fe}^{2+}$, $\mathrm{Zn}^{2+}$ and $\mathrm{Ca}^{2+}$ results in decreased uptake of lead and cadmium in plants (Khan and Frankland, 1983), Sandstead, 1995).

Conclusion: Trace metal (Fe, $\mathrm{Zn}, \mathrm{Cu}, \mathrm{Ni}$ and $\mathrm{Cd}$ ) levels of staple foods (yam, cassava, cocoyam and maize) from oil-producing areas were higher than those of non-oil producing area (Abakaliki). Because of these high trace metal levels, the staple foods from oil-producing areas examined are likely to be the major source of exogenous contamination of these metals in the populace. The results obtained from this study provide sufficient trigger for the government to undertake a survey of the health status of the populace from oil-producing areas as well as a more comprehensive environmental audit, health screening and monitoring which will be required to reveal the occupational and environmental hazards to which these areas are exposed.

\section{REFERENCES}

Adam, R.S. and Ellis, R. (1960): Some Physical and Chemical Changes in Soil brought about by Saturation with Natural Gas Soil Sci. Soc. Amer. Proc. 24. 41-44.
Bomen, H.J.M. (1966): Trace Elements in Biochemistry Academic Press London.

Crosby, N.T. (1977): Determination of Metals in Foods. The Analyst 102-267.

Eka, O.U. and Hobbis, C. (1987): Effect of Cooking on Nutrient Status of Danwake Nigeria J.Sc. 12, 317-325.

Ezeonu, F.C. Amanabo, M; Udedi, S.C.; Edeogu, O-C (2002): Iron and Zinc Status in Soils, Water and Staple Food Cultivars in Itakpe, Kogi State of Nigeria. The Environmentalist 22: 237-240.

Goyer, R.A.; Chevian, M.G. (1992): Role of Metallothioneri in Human Placenta and Ratexposed to Cadmium. In Nordberg G.E.; Herber R.F.M. Alessia eds. Cadmium in the Human Environment. Toxicity and Carcinogeincity. Lyon, France, ARC: 239-247.

Guthrie, H.A.; Picciano, M.F. (1995): Nutrition and Pregnancy in Human Nutrition. Mosby Year Book Inc. 303-542.

Hill, C. (1976): Mineral Interrelationships in Prasad. A Oberleas, D. (eds). Trace Elements in Human Health and Disease. New York Academy Press 281-300.

John, M.K. and Vanlaerhovon, C.J. (1972): Lead Distribution in Plants Grown on a Contaminated Soil environ Lett 3(2): 111-6.

John, M.K., Vanlaerhoven, C.J. and Chukwuma. C. (1972): Factors Affecting Plant Uptake and Phytotoxicity of Cadmium Added to Soils. Environmental Sci. \& Tech. 6(12): 105-1009.

Kakulu, S.E.; Osibanjo, O. and Ajayi, S.O. (1985): Trace Metal Content of Fish and Shell Fish of the Niger Delta Area of Nigeria Environ. Int. 13, 247-251.

Khan, D.H. and Frankland, B. (1983): Effects of Cadmium and Lead on Radish Plants with particular Reference to Movements of Metals through Soil Profile and Plant. Plant \& Soil 70, 335-345.

Kobayashi, H. and Rithman, B.E. (1982): Microbial Removal of Hazardous Organic Compounds Environ. Sci. Technol 19(3), 470-481A.

Macrae, R.; Robinson, R.K. and Sadler, M.J. (1993): Encyclopaedia of Food Science, Food 
Technology and Nutrition. New York Academic Press 3, 557-565, 4: 2573-2581, 3665-2672.

Sandstead, H.H. (1995): Requirements and Toxicity of Essential Trace Elements, Illustrated by Zinc and Copper Amr. J. Clin Nutri; 61 (Supply.): 6215-45.

Smith, L.R. and Dragun, J. (1984): Degradation of volatile Chlorinated Aliphatic Priority Pollutants in Groundwater. Environ. Int. 10. 291-298.

Tabaku, A. and Panariti, E. (196): Lead Intoxication in Rural Albania. Vet. Hum. Toxicol 38, 434435.

Wagner, A. and Miehlich, G. (1992): Cation Exchange in Artificial Oil Contaminated Soil Materials Mittellungen-der Deutshcen Bandenkundlichen-Gesellschaff 68, 301-304.
Watanebe, T. Nakatauka, H. and Ikedia, M. (1989): Cadmium and Lead Contents in Rice Availabe in Various Areas of Asia. Sci.-Total Environ. 80, 175-184.

Watanabe, T. Fuijita, H. Koizumi, A. Chiba, K, Miyasaka, M. and Ikedia, M. (1985): Dietary Cadmium Intakes of Farmers in non-polluted areas in Japan and the relation with Blood Cadium Levels Environ. Res 37: 33-43.

Wayne, A.P. and Dale, B.H. (1989): Understanding your Health, 2 ${ }^{\text {nd }}$ ed,, p. 107 St. Louis: Times Mirror/Mosby College Publishing.

World Health Organisation and International Programme on Chemical Safety (1991): Environmental Health Criteria for Nickel. International Programme on Chemical Safety (IPCS): EHO 108: 12-25, 146-151. 